Chirurgia (2020) 115: 112-119

No. 1, January - February

Copyright $@$ Celsius

http://dx.doi.org/10.21614/chirurgia.115.1.112

\title{
Postoperative Ileus Complicated with Incomplete Evisceration after Hysterectomy for Benign Pathology
}

\author{
Aida Petca ${ }^{1,2}$, Andreea Borislavschi ${ }^{2^{*}}$, Mihai Cristian Dumitrascu ${ }^{1,3}$, Florica Sandru ${ }^{1,4}$, Marinel Geoarsa ${ }^{5}$, \\ Razvan Cosmin Petca ${ }^{1,6}$ \\ "'Carol Davila" University of Medicine and Pharmacy, Bucharest, Romania \\ 2Department of Obstetrics and Gynecology, Elias University Emergency Hospital, Bucharest, Romania \\ ${ }^{3}$ Department of Obstetrics and Gynecology, University Emergency Hospital, Bucharest, Romania \\ ${ }^{4}$ Department of Dermatology, Elias University Emergency Hospital, Bucharest, Romania \\ ${ }^{5}$ Department of General Surgery, Elias University Emergency Hospital, Bucharest, Romania \\ ${ }^{6}$ Department of Urology, "Prof. Dr. Th. Burghele" Clinical Hospital, Bucharest, Romania
}

Corresponding author:

Andreea Borislavschi MD

Department of Obstetrics and Gynecology

Elias University Emergency Hospital,

17 Marasti bld., District 1, 011461

Bucharest, Romania

E-mail: andreea.borislavschi@gmail.com

\section{Rezumat}

Ileus dinamic postoperator complicat cu evisceratie blocată după histerectomie pentru patologie benignă

Ileusul dinamic postoperator (POI) este un fenomen complex cu morbiditate şi mortalitate importante, bine cunoscut în multe specialități chirurgicale. POI apare frecvent în chirurgia abdominală şi pelvină, în special la pacienții oncologici. Raportăm cazul unei paciente în vârstă de 63 de ani, fără factori de risc cunoscuți pentru POI, căreia i s-a practicat histerectomie totală cu anexectomie bilaterală pentru o suspiciune de tumoră ovariană malignă, invalidată de examenul histopatologic extemporaneu. Evoluția postoperatorie este marcată de activitate intestinală redusă, cu lipsa tranzitului intestinal pentru gaze şi materii fecale timp de 6 zile, perioadă în care a fost instituit tratamentul şi prevenirea POI în colaborare cu Chirurgia Generală, fără efect. Abdomenul a fost destins, fără greață sau vărsături. Complicațiile au apărut în a 6-a zi postoperatorie, cu eviscerație blocată, după ce a fost solicitată o tomografie a abdomenului şi regiunii pelvine pentru a elimina suspiciunea unei mase tumorale sau o patologie care implică zona intestinală. După reintervenție, pacienta şi-a reluat tranzitul pentru gaze şi materii fecale, dar au apărut alte 2 complicații, care au fost tratate cu succes: sepsis şi tromboză venoasă profundă. Ințelegerea fiziopatologiei ar putea ajuta la prevenirea, diagnos- 
ticarea şi punerea în aplicare a protocoalelor pentru a evita POI şi complicațiile sale, pentru a reduce durata spitalizării şi, implicit, costurile.

Cuvinte cheie: POI, eviscerațieblocată, măsuri de profilaxie, tromboembolism

\begin{abstract}
Postoperative ileus (POI) is a complex phenomenon with important morbidity and mortality, well known in many surgical fields. POI occurs commonly after abdominal and pelvic surgery, especially in cancer patients. We report the case of a 63-year-old patient without known risk factors for POI, who underwent total hysterectomy with bilateral adnexectomy for ovarian tumor with suspicion of malignancy, invalidated by the extemporaneous pathology examination. The postoperative evolution is marked by reduced bowel movements, lack of intestinal transit for flatus and stool for 6 days. In cooperation with the general surgeon conservative treatment for POI was administered, without effect. The abdomen remained distended, with no nausea or vomiting. On the $6^{\text {th }}$ postoperative day a wound dehiscence with incomplete evisceration occurred, after a CT scan of the abdomen and pelvic region was requested to make a differential diagnosis between an intestinal mass and other pathology involving the bowell. In conjunction with the General Surgery team the surgical reintervention was decided and performed. After the procedure, the patient successfully regained transit, with flatus and stool emission, but another 2 complications occurred, which were successfully treated: sepsis and deep vein thrombosis. Understanding the pathophysiology could help to prevent, diagnose, and implement protocols in order to avoid POI and its complications, to reduce hospital stay and cost burden.
\end{abstract}

Key words: POI, incomplete evisceration, prophylaxis measures, thromboembolism

\section{Introduction}

Postoperative ileus (POI) is a complex phenomenon which occurs commonly after abdominal surgery, especially with oncological features. Nevertheless, there have been few cases for POI following hysterectomy in benign cases - a retrospective cohort study shows rates of $0.12-1.1 \%$ among the approximately 400.000 hysterectomies performed annually (1). The lack of a definition and criteria to diagnose this physiological arrest of gastrointestinal transit in response to surgical stress, makes this complication particularly difficult to approach (a degree of ileus can be expected in the early postoperative phase).

In the literature POI has a variable definition of interval from onset to resolution, ranging from 2-7 days according to different authors (2).
In 2013 Vather et al. conducted a metaanalysis concluding that for POI to be defined as, at least two of the following five signs should be present $(2,3)$ :

- nausea and vomiting,

- no tolerance for solid of semi-liquid diet during the previous 24 hours,

- no gas or stool for the previous 24 hours,

- abdominal distension,

- radiological evidence of ileus.

Several risk factors have been identified: male gender, elevated BMI, advanced age, use of opioids, previous abdominal surgery, hypokalemia, smokers, major blood loss, blood transfusions, concomitant appendectomy, contaminated wounds, uterine weight $(>250 \mathrm{~g})$, operating time (>170 min) $(1,2,4)$.

We report the management and evolution of a POI case from our clinic and discuss its particularity. 


\section{Case Report}

A 63-year old patient, gravida 6 para 3, at menopause since age 50, with BMI of 28.5, diagnosed on ultrasound and CT (abdomen and pelvis) right ovarian tumor with suspicion of malignancy, was admitted for chronic pelvic pain with partial remission after antiinflammatory medication. From the patient's history, a tendency for delayed intestinal transit stands out, with no prior surgical interventions or chronic treatment.

The preoperative pelvic CT scan described an enlarged right ovary, of 10/11/14 cm, with mixt content (Fig. 1) and the suspicion of malignancy was raised, without any other pathological findings, besides an enlarged abdominal cavity (Fig. 2). The gynecological examination is normal, except the right vaginal cul de sac, where a cystic tumor was palpated, approximately $10 \mathrm{~cm}$, supple and sensible. The trans-vaginal ultrasound highlighted cystically transformed right ovary, about $11 / 9 \mathrm{~cm}$, with thin walls and mixt content (solid and transonic with multiple septum without Doppler flow).

After a week, surgery is performed under general anesthesia by pubo-subumbilical laparotomy due to malignancy suspicion (fentanyl was used during anesthesia). Once the peritoneal cavity is opened the following were observed: the uterus had normal appearance and reduced size due to age, left adnexa and right fallopian tube with normal appearance and size, right ovary cystically transformed, about 10/11 cm with smooth surface and highly vascularized, regular outline, multiloculated, with mixt content. Intestinal peristalsis is reduced, but the bowels have a normal appearance and size. Right adnexectomy is performed (the operatory specimen is sent to extemporaneous pathology examination - mucinous and serous cysta-denoma). Total hysterectomy with left adnexectomy was then performed (no nasogastric tube was inserted). The surgical intervention lasted for 95 minutes, with normal blood loss. Postoperative recommendations were: permanent wearing of an abdominal elastic binder, early postoperative feeding and early ambulation.

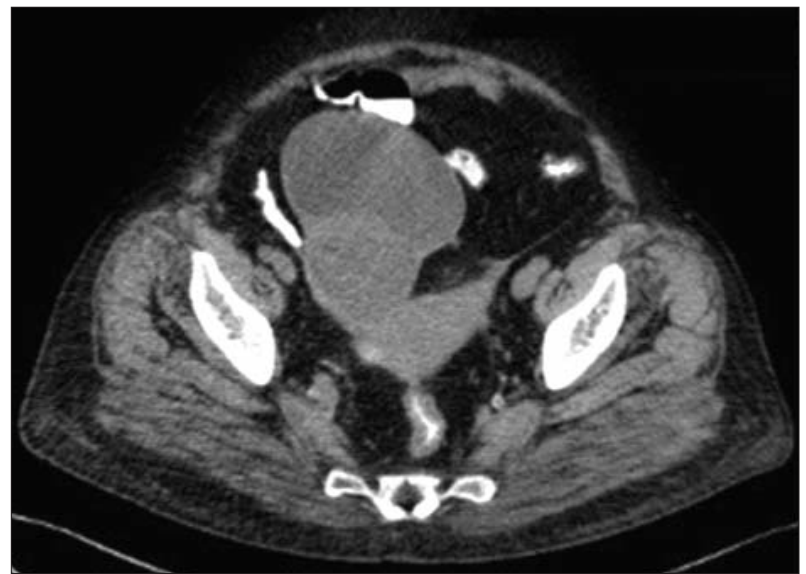

Figure 1. Pelvis CT with oral contrast, axial view, showing enlarged right ovarian tumor

During the immediate postoperative period the evolution is affected by reduced bowel movements and lack of intestinal transit for flatus and stool for 6 days; during this time, conservative treatment is attempted, with no effect (Table 1).

On the $4^{\text {th }}$ postoperative day (PO) a General Surgery consult is requested, and the following recommendations were: enema and

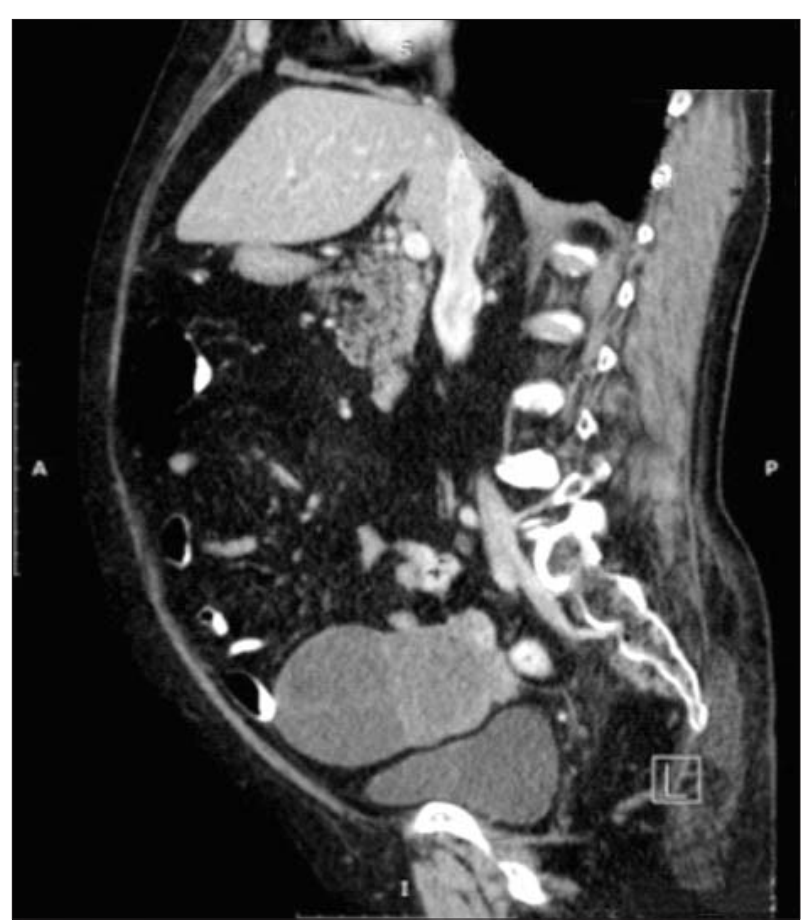

Figure 2. Abdominal and pelvis CT with oral contrast, sagital view, revealing enlarged abdominal cavity and ovarian tumor in the pelvic area 
Table 1. Primary prokinetic management

\begin{tabular}{ll}
\hline Metoclopramide $1 \mathrm{fi} / 12$ hours, subsequent at $8 \mathrm{~h}$ & Neostigmine1fi $\times 2$-3/day \\
\hline Domperidonum tb $10 \mathrm{mg} \times 2 /$ day & Enema \\
\hline Medicinal charcoal tb $2 \times 3 /$ day & Chewing gum \\
\hline Suppositories with glycerin $2 /$ day & Early ambulation \\
\hline Trimebutinum tb $200 \mathrm{mg} \times 3 / \mathrm{zi}$ & Coffee \\
\hline Lactulosum $10 \mathrm{ml} \times 2-3 /$ day & Early postoperative feeding \\
\hline Gas tube assembly & NSAlDs \\
\hline
\end{tabular}

abdominal $x^{-r a y}$ (no signs of pneumoperitoneum). The general status of the patient remained constant, with reduced bowel movements, lack of intestinal transit and abdominal meteorism, but without nausea and vomiting.

On the $6^{\text {th }}$ PO a contrast CT scan of the abdomen and pelvic region is requested, which showed a distended colon with mixt content, gas-fluid levels, the maximum size of transverse colon is $71 \mathrm{~mm}$ and cecum of $93 \mathrm{~mm}$; progressive decalibration of the colon towards pelvic region (Fig. 3). The indication for CT scan was the need to establish a differential diagnosis of an intestinal mass or other pathology involving the bowel. After the ingestion of $1.5 \mathrm{l}$ contrast solution the abdominal distention is aggravated with subsequent high intensity abdominal pain. General surgery consult is requested again and an incomplete

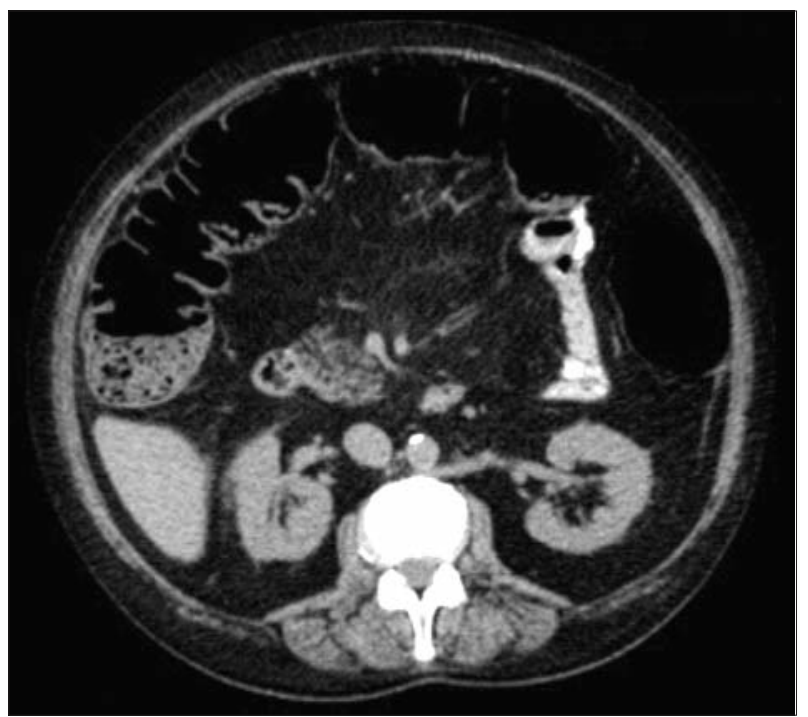

Figure 3. Abdominal CT with oral contrast, axial view, showing enlarged diameter for transvers colo evisceration is diagnosed. A nasogastric tube is inserted and consequently iterative surgical approach is decided.

During surgery, after the removal of the skin sutures, a dehiscence in the aponeurosis was found, about 8-10 cm wide, with evidence of previously suture underlying parietal peritoneum; intestines are inspected and palpated along the entire length, with no signs of peristalsis, nor space-occupying tumors, but with notable distension; a short ileal mesentery is observed. The sigmoid is adherent to the vaginal cuff - and the adhesion is unbound. Warm physiological saline solution is applied repeatedly and an anal sphincter dilatation is performed. A gas tube is inserted in the anus, guided transabdominally up to sigmoid. During surgery lidocaine was administered intravenously.

The patient was afterwards admitted to Intensive Care Unit, kept for closer observation and a special medical management was instituted (Table 2).

On the second day PO the patient underwent an enema and evacuated stool. On the $8^{\text {th }}$ day PO the patient was transferred into the Gynecological department presenting bowel movement and intestinal transit for flatus and stool (continuing with medication: enoxaparin $0.4 \mathrm{UI} /$ day, metoclopramide 1 fi x 2/day, laxatives, pantoprazole 1fi/12 hours).

On the $9^{\text {th }} \mathrm{PO}$ day the patient reported fever, when measured it was $39^{\circ} \mathrm{C}$, presenting many changes on the blood works. (elevated leukocytes with neutrophilia, CRP $>100$, normal procalcitonin). An Infectious Disease Specialist consult is requested and the following recommendations were obtained:

- nasopharyngeal culture - proved negative 
Table 2. Medical management after reintervention

\begin{tabular}{ll}
\hline Parenteral nutrition $1920 \mathrm{ml}(+10 \mathrm{lU}$ insulin + calcium $)$ Supportan, Addamel \\
\hline Ringer solution $1500 \mathrm{ml} /$ day & Human Albumin $20 \% 100 \mathrm{ml} /$ day \\
\hline Metoclopramide $1 \mathrm{gr} / 12 \mathrm{hours}$ iv & Neostigmine 1 at 8 hours \\
\hline Pantoprazole $1 \mathrm{f} / 12$ hours iv & Laxatives: Lactulose and Bisacodyl \\
\hline Lidocaine $1 \% 5 \mathrm{fi}(6 \mathrm{ml} /$ hour $)$ on syringe pump & $\begin{array}{l}\text { Hydric diet for the first } 4 \text { P0 days } \\
\text { Enoxaparin } 0.4 / \text { day }\end{array}$ \\
\hline Erythromycin tb $100 \mathrm{mg} \times 3 /$ day & \\
\hline
\end{tabular}

- rectal culture - proved negative

- postoperative incision culture Pseudomonas aeruginosa and Enterococcus faecium

- blood cultures- Enterococcus faecium

- Antibiotics: initially tigecycline $100 \mathrm{mg}$, then $50 \mathrm{mg} / 12$ hours, subsequent meropenem iv $1 \mathrm{fi} / 8$ hours and vancomycin iv $1 \mathrm{~g} / 8$ hours for the suspicion of enterococcus faecium - with favorable evolution

- CT scan of abdomen and pelvis, or ultrasound (ultrasound did not reveal abnormal fluids in the abdomen).

Secondary to the prolonged immobilization, part of the recovery measures, even if the prophylactic treatment with enoxaparin was accurately administered, the patients' right leg became edematous. A Doppler Ultrasound and a Cardiology consult were requested, diagnosing an acute deep vein thrombosis (iliofemoral-popliteal). Anticoagulant treatment was instituted (enoxaparin $0.6 \times 2$ /day) and a CT scan of the thorax was recommended (intralumenal lacunar images suggestive for thrombi located in subsegmentary arteries tributary to posterior and basal RIL - right inferior lobe and anterior LSL - left superior lobe segments) (Fig. 4).

The evolution was favorable, with the remission of the edematous right leg, intestinal transit present for stool, complete remission of the fever and completes healing of the operative wound. The patient was hospitalized for 30 days.

\section{Discussions}

For sure, in order to prevent and treat POI, mechanisms should be understood. The origins of POI seem to be multifactorial, based mainly on various changes of and on the enteric nervous system.

POI develops over three phases (2): sympathetic nervous system pathways (inhibits gastrointestinal motility (5), hormonal inflammatory mechanisms (proinflammatory molecules are increased in the walls of intestines, the permeability of the intestinal epithelial barrier is increased, therefore bacterial translocation can occur; the manipulation of intestines induces also inflammatory response), parasympathetic nervous activation (stimulates gastrointestinal motility (5)). The neurogenic phase emerges perioperatively and resolves early, but the inflammatory phase begins 3-4 hours following surgery and can last several days $(6,7)$. Surgery increases $\mathrm{ADH}$, cortisol and aldosterone (4), which leads to water and salt retention, therefore if the normovolemia is not maintained, the edema can increase the risk of POI.

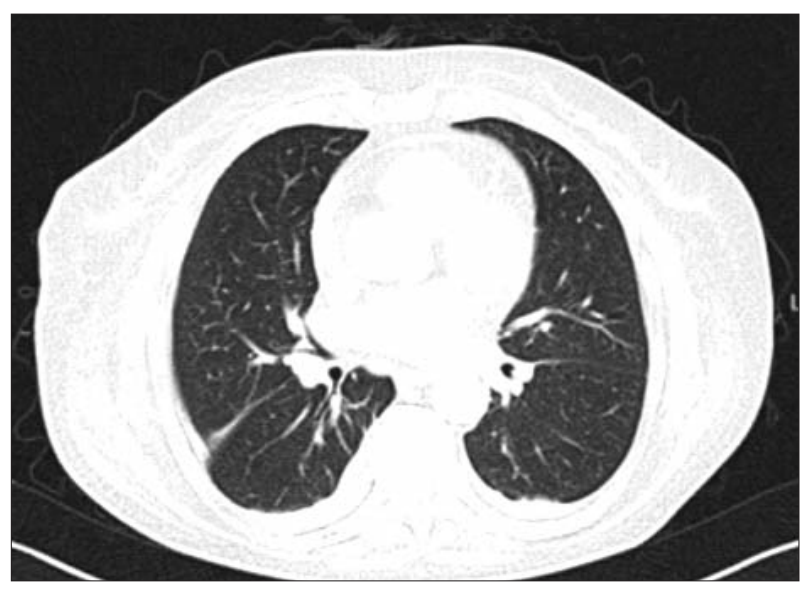

Figure 4. CT scan of the chest, axial view, showing signs of pulmonary embolism 
Therefore, the physiological stress of surgery can cause a period of intestinal paralysis, and the return of gastrointestinal motility occurs in stages: small bowel between 0 and 24 hours, stomach between $24-48$ hours and the colon between 48-72 hours $(4,8)$.

Type definition (8):

- Nausea, vomiting, and failure to pass flatus or stool - affects the entire gastrointestinal tract;

- Nausea and vomiting, but with the presence of colonic activity- affects the upper gastrointestinal tract;

- Manifests as no passage of flatus and/or stool, but with tolerance of diet.

Normal bowel function requires the coordination of more than one action: gastrointestinal motility, mucosal transport and defecation reflexes, which are influenced by neurogenic, inflammatory and pharmacological mechanisms. These "devices" can be altered by both surgery and anesthesia.

The clinical presentation of POI overlaps with the early postoperative small bowel obstruction, and is essential to differentiate between the two and investigate further. Ineffective bowel motility results in gastrointestinal secretions accumulating in the lumen and manifests as abdominal pain, symmetrical distention of the abdomen, nausea and vomiting (which can be complicated by pulmonary aspiration) and failure to pass flatus and stool. Other complications include dehydration, electrolyte imbalance, nutrient reabsorption which can lead to compromised immune system and the risk of sepsis. Prolonged POI can also lead to deep vein thrombosis, decreased mobility, pain and discomfort (8).

Other cases of POI have been reported post cesarean section (9) and in patients with bowel endometriosis (5-12\%: most of the bowel lesions are located in rectosigmoid - 50-90\%; but it can also affect ileum in 2-16\%) (10).

Some studies showed that insertion of naso-gastric tube should be avoided in order to prevent POI (4). Authors have grouped together a variety of therapeutically measures with the aim of preventing POI (Table 3).

Many authors divided the strategies when treating POI into prevention and supportive care. When preventing POI one should carefully analyze the choice of anesthesia, including, when possible, epidural analgesia and the surgical technique, thus reducing surgery duration.

In our case, the postoperative evolution was surprisingly unfavorable in a patient

Table 3. Recommended therapy measures for POI prevention

\begin{tabular}{|c|c|}
\hline Treatment $(2,4-6,8,11)$ & Prevention $(2,4-6,8,12-14)$ \\
\hline Alvimopan(phase 1) - antagonist of the $\mu$ opioid receptor & Epidural analgesia \\
\hline Both exogenous and endogenous activation of $\mu$-opioid & Opioid free analgesia \\
\hline receptors in the gastrointestinal tract is linked to inhibition & Surgical approach \\
\hline of gut motility & The main mechanisms of $\mathrm{POI}$ involve phase 2 - \\
\hline Neostigmine & inflammatory response. In laparotomy the risk of POI \\
\hline Stimulates the parasympathetic activity & is higher than in laparoscopy approach \\
\hline Lidocaine - intravenous infusion (phase 1) & (intestinal manipulation) \\
\hline Reduces pain and sympathetic stimulation. & Chewing gum \\
\hline NSAIDs - phase 2 & Stimulates vagal tone, which has an anti-inflammatory \\
\hline Reduces inflammation by their action on COX2 or COX1 & effect (phase 3 of ileus) \\
\hline Prokinetic agents & Nicotine \\
\hline $\begin{array}{l}\text {-Intravenous Magnesium (sulfate magnesium } 40 \mathrm{mg} / \mathrm{kg} \text { in } \\
\text { bolus and an infusion of } 10 \mathrm{mg} / \mathrm{kg} \text { during surgery) } \\
\text { - Metoclopramide }\end{array}$ & $\begin{array}{l}\text { Administration of nicotine induces acceleration in } \\
\text { colonic transit followed by relaxation of the descending } \\
\text { colon. }\end{array}$ \\
\hline -Choline citrate & Coffee \\
\hline -Mosapride citrate & Early postoperative feeding \\
\hline -Erythromycin & Ambulation \\
\hline -Gastrografin & \\
\hline
\end{tabular}


without known risk factors, who underwent a total hysterectomy for a benign condition and developed POI, even if the recommended prophylaxis measures were early instituted: gum chewing, early feeding and ambulation. The case later complicated with incomplete evisceration followed by an iterative laparotomy that didn't find additional pathological features.

As it stands out from our case, the prevention and especially the treatment measures were first and early instituted and no beneficial outcome was obvious. On the contrary, the case evolution was towards incomplete evisceration, caused by the important distention of the abdomen, after the gastrografin ingestion, even if many studies recommend it as a treatment for POI (4). Preoperative nutrition was properly recommended: fasting at least 6 hours for solid food and 2 hours for liquids (2). When discussing the surgery, it lasted only 95 minutes, no nasogastric tube was inserted preoperatively and the blood loss was in normal range. The patient reported in the first two days PO flatus, bowel sounds, and we relied on these details. Later on, the patient's report proved as misleading and the treatment instituted became more aggressive in order to regain bowel function, without positive response. Thus, the patient was early fed and ambulated; prokinetics, laxatives, neostigmine and NSAIDs were administered, as well as coffee and chewing gum. To prevent evisceration, the patient wore an abdominal elastic binder. After the reintervention, the resolution of POI was retrieved after 5 days of intensive care measures: early ambulation, chewing gum, Lidocaine $1 \%$ on syringe pump, Erythromycin tb, Laxatives: Lactulose and Bisacodyl, Neostigmine, Parenteral nutrition, Human Albumin 20\% $100 \mathrm{ml} /$ day. Later on the patient developed Enterococcus faecalis sepsis and deep vein thrombosis, which were both treated accordingly.

Studies conducted so far (1) conclude that amvilopan (agent that inhibits peripheral mu-opioid receptors and abolishes the adverse gastrointestinal effects of opioids) is the wright answer for the cases complicated with
POI. POI complicating benign hysterectomies were treated successfully with amvilopan, thus this should be comprised by the medical management in such case (15).

Most of the cases reported so far are POI after intestinal surgery, so fasting and liquid diet is usual, thus these would act as independent risk factors. Still, many authors declare that the great majority of POI resolves with watchful waiting and complementary treatment: intravenous hydration, correction of acid base and electrolyte abnormalities, mending the substratal medical status.

Our patient was healthy discharged and shall return to programmed follow-ups. As other studies report $(1,15)$, the hospitalization lasted for a long time (30 days) and was rather expensive. Cases like that are a burden for hospitals, thus prophylaxis measures for POI is mandatory for every surgical case.

\section{Conclusions}

POI is a major cause of postoperative morbidity and mortality, well known in many surgical fields. Emerging ways to prevent, diagnose and treat POI can contribute in reducing hospital stay and cost burden. From our case we can conclude that despite promptly instituted prevention measures and treatment methods described so far (alvimopan is not available in Romania), POI complicated with incomplete evisceration secondary to important abdominal distention.

Further research, better prophylaxis and implementation of enhanced recovery protocols are needed in order to avoid POI and its complications.

\section{Conflict of Interest}

The authors declare no conflicts of interests.

\section{References}

1. Sheyn D, Bretschneider CE, Mahajan ST, Ridgeway B, Davenport A, Pollard R. Incidence and risk factors of early postoperative small bowel obstruction in patients undergoing hysterectomy for benign indications. Am J Obstet Gynecol. 2019;220(3):251.e1-251.e9.

2. Venara A, Neunlist M, Slim K, Barbieux J, Colas PA, Hamy A, et al. Postoperative ileus: Pathophysiology, incidence, and prevention. $J$ 
Visc Surg. 2016;153(6):439-46.

3. Vather R, Trivedi S, Bissett I. Defining postoperative ileus: results of a systematic review and global survey. J Gastrointest Surg 2013; 17(50:962-72.

4. Bragg D, El-Sharkawy AM, Psaltis E, Maxwell-Armstrong CA, Lobo DN. Postoperative ileus: Recent developments in pathophysiology and management. Clin Nutr. 2015;34(3):367-76.

5. Zeinali F, Stulberg JJ, Delaney Cp. Pharmacological management of postoperative ileus. Can J Surg. 2009;52(2):153-7.

6. Funder JA, Tolstrup R, Jepsen BN, Iversen LH. Postoperative paralytic ileus remains a problem following surgery for advanced pelvic cancers. J Surg Res. 2017;218:167-73.

7. Calu V, Dumitrescu D, Miron A. The place of laparoscopy in the surgical treatment of scleroatrophiccholecystitis. Chirurgia (Bucur). 2010;105(5):653-6.

8. Carroll J, Alavi K. Pathogenesis and Management of Postoperative Ileus. Clin Colon Rectal Surg. 2009;22(1):47-50.

9. Norton-Olda KJ, Yuen N, Umstadb MP. An Obstetric Perspective on Functional Bowel Obstruction after Cesarean Section: A Case Series. J Clin Gynecol Obstet. 2016;5(1):53-7.

10. Barbosa RN, Andres MP, Kho RM, Abrăo MS. Ileum Endometriosis:
A Cause of Bowel Obstruction. J Minim Invas Gyn. 2018;25(5): 759-60.

11. Petca A, Radu DC, Petca RC, Mehedintu C, Barac RI, Ionescu A, et al. Current trends of liquid chromatography tandem mass spectroscopy use in clinical gynecology. Rev Chim Bucharest. 2019;70(6):2021-5.

12. Balayla J, Bujold E, Lapensée L, Mayrand MH, Sansregret A. Early Versus Delayed Postoperative Feeding After Major Gynaecological Surgery and its Effects on Clinical Outcomes, Patient Satisfaction, and Length of Stay: A Randomized Controlled Trial. J Obstet Gynaecol Can. 2015;37(12):1079-85.

13. Timofte D, Ochiuz L, Ursaru M, Ciuntu B, Ionescu L, Calu V, et al. Biochemical Modifications Related to Calcium Deficiencies in Obesity and After Laparoscopic Sleeve Gastrectomy. Rev Chim Bucharest. 2017:68(10):2341-5.

14. Patrasescu M, Nuta P, Costache RS, Bucurica S, Macadon B, Balaban V, et al. Physical effort - an underused preventable method in colorectal cancer. Rom J Mil Med. 2018;121(2):41-45.

15. Taguchi A, Sharma N, Saleem RM, Sessler DI, Carpenter RL, Seyedsadr M, Kurz A. Selective postoperative inhibition of gastrointestinal opioid receptors. N Engl J Med. 2001;345(13):935-40 